\begin{tabular}{|l|l|l||}
\hline \multicolumn{2}{|c|}{ PublisherInfo } \\
\hline \hline PublisherName & $:$ & BioMed Central \\
\hline \hline PublisherLocation & $:$ & London \\
\hline \hline PublisherImprintName & $:$ & BioMed Central \\
\hline \hline
\end{tabular}

\title{
Molecular evolution of language
}

\begin{tabular}{|l|l|l||}
\hline \multicolumn{2}{|c|}{ ArticleInfo } \\
\hline \hline ArticleID & $:$ & 4555 \\
\hline \hline ArticleDOI & $:$ & $10.1186 /$ gb-spotlight-20020815-01 \\
\hline \hline ArticleCitationID & $:$ & spotlight-20020815-01 \\
\hline \hline ArticleSequenceNumber & $:$ & 221 \\
\hline \hline ArticleCategory & $:$ & Research news \\
\hline ArticleFirstPage & $:$ & 1 \\
\hline \hline ArticleLastPage & $:$ & 3 \\
\hline \hline & & RegistrationDate : 2002-8-15 \\
\hline ArticleHistory & $:$ & OnlineDate \\
\hline \hline ArticleCopyright & $:$ & BioMed Central Ltd2002-8-15 \\
\hline \hline ArticleGrants & $:$ & \\
\hline \hline ArticleContext & $:$ & 130593311 \\
\hline \hline
\end{tabular}




\section{Michaela Torkar}

Email: michaelatorkar@hotmail.com

The ability of humans to develop a proficient spoken language has probably driven the development of a culture distinct from that of chimpanzees and other apes. Speech depends on fine control of the larynx and mouth, which our closest relatives lack. FOXP2, a member of the forkhead transcription factor family, was the first gene associated with the development of speech and language in humans. A point mutation in FOXP2 is associated with a severe speech and language disorder in a family in which half the members are affected. In the 14 August advanced online Nature, Svante Pääbo and researchers at the Max Planck Institute for Evolutionary Anthropology, Leipzig, Germany, and the University of Oxford, UK, report that two amino-acid changes in human FOXP2 have been under positive selection in the human lineage and were probably fixed at (or following) the time when modern humans emerged (Nature 2002, doi:10.1038/nature01025).

Pääbo and colleagues show that human FOXP2 differs in the coding of two amino acids from chimpanzee, gorilla, orang-utan, rhesus monkey and from mouse. A third amino-acid difference is found between human and mouse, but not between human and other apes. Exon 7, which encodes the two amino acids, is highly conserved among humans, and no amino-acid polymorphism was found in 44 human chromosomes from all major continents. Analysis of allele frequencies in humans and apes indicated that the two amino-acid replacements specific to humans are the best candidates for selected sites. This FOXP2 variant was probably fixed in the human population during the past 200,000 years and may have enabled humans to control orofacial movements and therefore the development of speech.

\section{References}

1. Lai CSL, Fisher SE, Hurst JA, Vargha-Khadem F, Monaco AP.: A forkhead-domain gene is mutated in a severe speech and language disorder. Nature 2001, 413:519-523.

2. Enard W, Przeworski M, Fisher SE, Lai CSL, Wiebe V, Kitano T, Monaco AP Pääbo S.: Molecular evolution of FOXP2, a gene involved in speech and language. Nature 2002, doi:10.1038/nature01025., [http://www.nature.com]

3. Max Planck Institute for Evolutionary Anthropology, [http://www.eva.mpg.de/]

4. University of Oxford, [http://www.ox.ac.uk/] 
(c) 2009-2013. SPi Global, Chennai, India. All rights reserved. 